\title{
An AutoAnalyzer method for estimating serum glyceride glycerol using a glycerokinase procedure
}

\author{
JOYCE L. BELL, SUSAN M. ATKINSON, AND D. N. BARON \\ From the Department of Chemical Pathology, Royal Free Hospital, London
}

SYNOPSIS The glyceride glycerol analysis depends, after saponification of triglycerides, on a linked enzymatic procedure using glycerokinase, pyruvate kinase, and lactate dehydrogenase: $\frac{\mathbb{D}}{O}$ the final conversion of NADH to NAD ${ }^{+}$is followed fluorimetrically. Twenty analyses can be performed per hour on the AutoAnalyzer; recoveries of added triglycerides ranged between 90 and $104 \%$. In a mixed male and female group the normal range for glyceride glycerol was 2.5 to $15.5 \mathrm{mg} / 100 \mathrm{ml}(0 \cdot 2-1.4 \mathrm{mmol} / \mathrm{l})$ fasting, and 2.5 to $18.0 \mathrm{mg} / 100 \mathrm{ml}(0 \cdot 2-1.6 \mathrm{mmol} / \mathrm{l})$ postprandially using fresh serum. There was a significant rise postprandially in older men.

There are increasing requests for the estimation of serum triglycerides, particularly since the introduction of the drug clofibrate (Atromid-S).

Triglycerides are normally measured as glyceride glycerol and there are a number of different types of method available, eg, manual colorimetric (Carlson and Wadström, 1959), manual enzymatic (Wieland, 1957; Eggstein and Kreutz, 1966), automatic fluorimetric (Kessler and Lederer, 1965), and automatic colorimetric (Lofland, 1964). Colorimetric and fluorimetric methods require preliminary treatment of the sample to remove interfering substances and impart specificity, and we felt, therefore, that automation of a specific enzymatic method would be useful. The automated method described in this paper is based on the enzymatic method of Eggstein and Kreutz (1966) and depends on the following reactions:

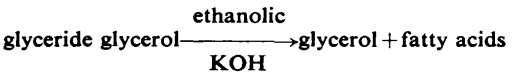

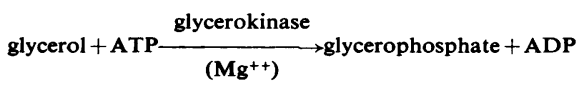

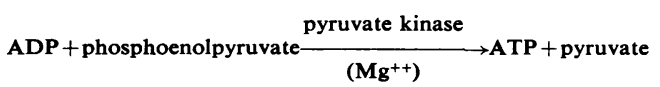

$$
\begin{aligned}
& \text { pyruvate }+\mathrm{NADPH}+\mathrm{H}^{+} \stackrel{\text { lactate dehydrogenase }}{\longrightarrow} \text { lactate }+\mathrm{NAD}^{+}
\end{aligned}
$$

Received for publication 30 December 1969.

\section{Materials and Methods}

\section{APPARATUS}

The Technicon AutoAnalyzer was used attached to a Locarte fluorimeter (model LFM/5) with a flow-through cell and a Rikadenki recorder. An LF.1 filter was used on the primary (excitation) side, and a wavelength of $470 \mathrm{~nm}$ with a cut-out filter, LF.6, on the secondary (emission) side. The LF. 1 filter transmits between 254 and $400 \mathrm{~nm}$. The LF.6filter transmits light only of wavelengths greater than $470 \mathrm{~nm}$.

\section{REAGENTS}

Ethanolic $\mathrm{KOH}(0 \cdot 5 \mathrm{~N})$

Dissolve $6 \mathrm{~g}$ glycerol-free KOH (Griffin and $\underset{\omega}{N}$ George) in $200 \mathrm{ml}$ absolute ethanol. The normality of this solution should be checked by titration and 0 appropriately diluted with absolute ethanol to bring it to $0 \cdot 5 \mathrm{~N}$.

$\mathrm{MgSO}_{4}(0 \cdot 1 \mathrm{M})$

Dissolve $5.0 \mathrm{~g} \mathrm{MgSO}_{4} 7 \mathrm{H}_{2} \mathrm{O}$ A.R. in $200 \mathrm{ml}$ distilled water.

Triethanolamine buffer $(0 \cdot 1 \mathrm{M}, \mathrm{pH} 7 \cdot 6)$ containing $0.004 \mathrm{M} \mathrm{MgSO}_{4}$ (solution $\mathrm{A}$ )

Dissolve $37.2 \mathrm{~g}$ triethanolamine hydrochloride 
A.R. and $1.972 \mathrm{~g} \mathrm{MgSO}_{4} 7 \mathrm{H}_{2} \mathrm{O}$ A.R. in $1,500 \mathrm{ml}$ distilled water, bring the $p \mathrm{H}$ to 7.6 with $\mathrm{N} \mathrm{NaOH}$ (about $80 \mathrm{ml}$ ), and dilute to 2 litres with distilled water. Stable at $4^{\circ} \mathrm{C}$.

Phosphoenolypyruvate $(0.011 \mathrm{M})$ and ATP $(0.033 \mathrm{M})$ (solution B)

Dissolve 0.363 g ATP (Boehringer) and $0.045 \mathrm{~g}$ phosphoenolpyruvate (Boehringer) in $20 \mathrm{ml}$ of the triethanolamine buffer (solution A). Stable for at least two weeks at $4^{\circ} \mathrm{C}$.

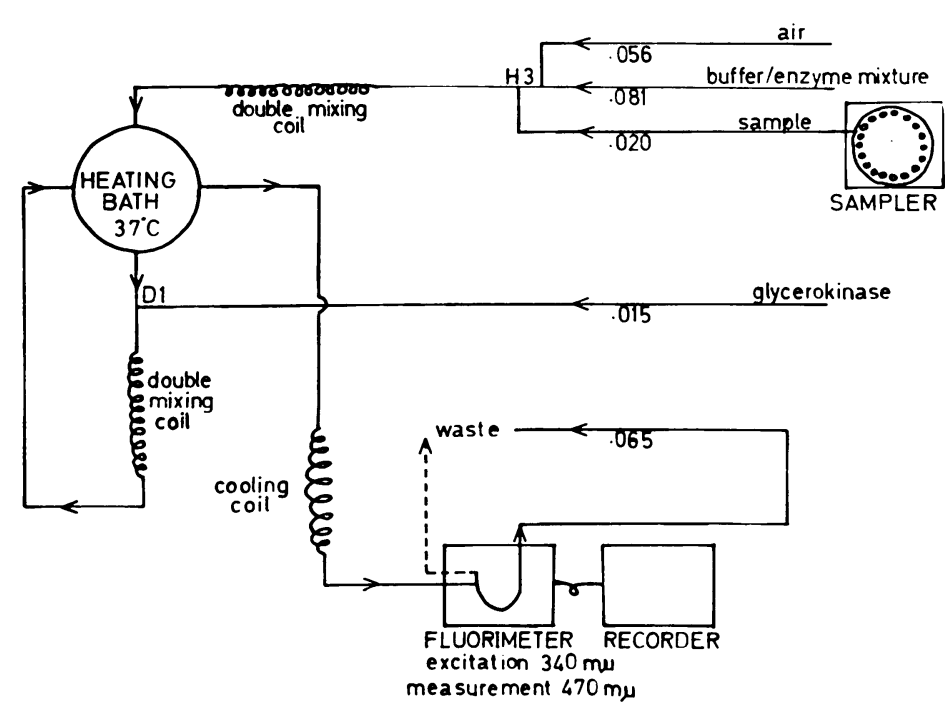

Fig. 1 Diagram of AutoAnalyzer manifold for determination of serum glyceride glycerol.

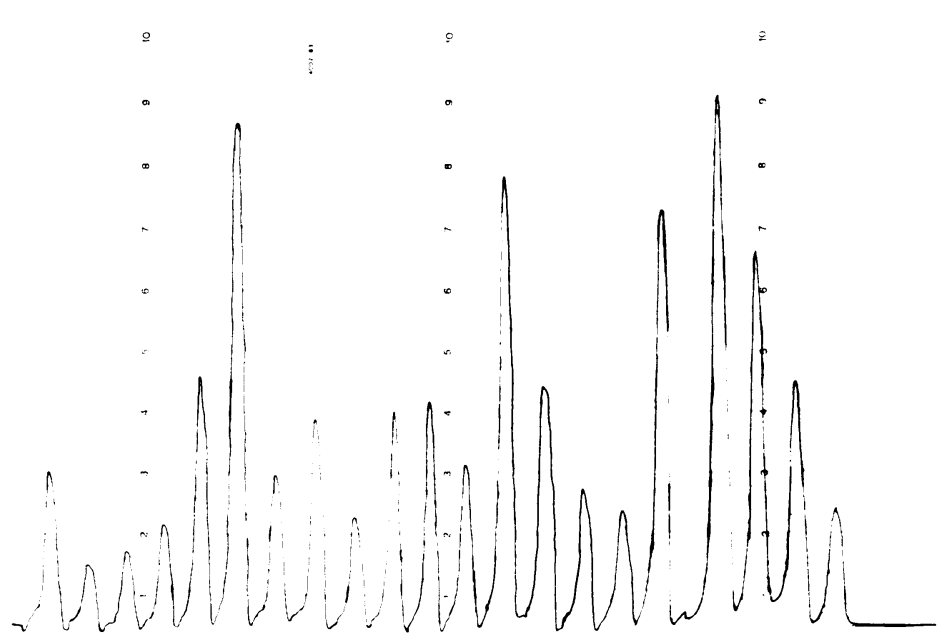

Fig. 2 Calibration curve for standard glycerol solutions on the right (first four samples), followed to the left by typical AutoAnalyzer tracing for glyceride glycerol determination.
Lactate dehydrogenase $(2 \mathrm{mg} / \mathrm{ml})$ pyruvate kina $\frac{{ }^{c}}{5}$ ( $1 \mathrm{mg} / \mathrm{ml})$ (solution C)

Mix $4 \mathrm{ml}$ lactate dehydrogenase solution $(5 \mathrm{mg} / \mathrm{m}$ 竞, specific activity about $360 \mathrm{u} / \mathrm{mg}$, Boehringer) wi $1 \mathrm{ml}$ pyruvate kinase $(10 \mathrm{mg} / \mathrm{ml}$, specific activity about $150 \mathrm{u} / \mathrm{mg}$, Boehringer) and $5 \mathrm{ml}$ normâl saline. Stable for at least two weeks at $4{ }^{\circ} \mathrm{C}$.

\section{NADH $(0.018 M)$ (solution D)}

Dissolve $24 \mathrm{mg}$ NADH (Sigma) in $2 \mathrm{ml}$ aqueoßs sodium chloride solution $(0 \cdot 15 \mathrm{M}$ : isotongc saline). Prepare freshly for each batch of analyses.

\section{Buffer-enzyme mixture}

Mix $500 \mathrm{ml}$ solution A with $10 \mathrm{ml}$ solution 免 and $2.4 \mathrm{ml}$ solution $\mathrm{C}$. Add $2 \mathrm{ml}$ solution $\overline{8}$. This is sufficient reagent for the standards and about 24 tests and blanks, and should be prepareg freshly for each day's run.

\section{Glycerokinase $(0.05 \mathrm{mg} / \mathrm{ml})$}

Dilute $0.1 \mathrm{ml}$ glycerokinase $(5 \mathrm{mg} / \mathrm{ml}$ specific activity about $85 \mathrm{u} / \mathrm{mg}$ Boehringer) to $10 \mathrm{rg}$ with normal saline. Prepare freshly for each bates of analyses.

Stock standard glycerol $(10 \mathrm{mg} / 100 \mathrm{ml})$

Dissolve $10 \mathrm{mg}$ glycerol A.R. (BDH) in distilled water to a volume of $100 \mathrm{ml}$.

\section{Working glycerol standards}

Dilute $10,20,30$, and $40 \mathrm{ml}$ stock glycerब solution each to $100 \mathrm{ml}$ with distilled water give working standards of $1,2,3$, and $4 \mathrm{mg} / 100$ 骨 respectively.

\section{METHOD}

\section{Saponification}

Pipette $0.2 \mathrm{ml}$ fresh serum and $0.5 \mathrm{ml}$ ethanotic $\mathrm{KOH}(0 \cdot 5 \mathrm{~N})$ into a centrifuge tube. Stopper, $\mathrm{m} \underset{\mathrm{X}}{\mathrm{X}}$, and saponify in a water bath at $70^{\circ} \mathrm{C}$ for $\mathrm{BO}$ minutes. Cool, add $1.5 \mathrm{ml} \mathrm{MgSO}_{4}$ solution, shake well and centrifuge for 10 minutes. The clegr supernatant is used for assay of the total glyceride glycerol. The supernatant can if necessary be left at room temperature overnight before analysis

\section{Operating procedure}

A diagram of the AutoAnalyzer manifold shown in Figure 1. A 2:1 cam is used with of Technicon sampler 2. The fluorimeter should हुe switched on at least 30 minutes before use $\bar{\Phi}$ allow it to stabilize. The photomultiplier ared 'shorted direct' switches should be switched of about 10 minutes before the start of the ruō. Place the buffer-enzyme mixture in an ice bati Aspirate the buffer-enzyme mixture for $\mathrm{B}$ minutes, with the glycerokinase tube pumping buffer. After about 10 minutes' aspiration, sample the standards and tests at a speed of 40 per hour alternatively with water, ie, 
samples per hour. After about 12 minutes' aspiration, ie, a further two minutes, place the glycerokinase tube in the glycerokinase mixture: this procedure avoids undue waste of the glycerokinase solution. After about 15 minutes' aspiration (a further three minutes) the buffer-enzyme mixture will reach the fluorimeter, when the base line should be adjusted. About 12 minutes after the last test has been aspirated the glycerokinase can be stopped and the blanks run. The blanks are run in the same way as the tests except buffer is pumped through the glycerokinase line continuously. The times given are approximate and depend on the details of construction of the manifold.

\section{Calculation}

A calibration curve is drawn for the standards and $\mathrm{mg}$ glycerol/100 $\mathrm{ml}$ read off for the tests and blanks. Then:

(test-blank) $\times 11=\mathrm{mg} /$ glyceride glycerol per $100 \mathrm{ml}$ serum

or

$($ test-blank $) \times 11 \times 10 / 92=\mathrm{mmol}$ glyceride glycerol per litre.

\section{Results}

\section{CALIBRATION CURVE}

A typical calibration curve is shown in Figure 2. The curve is linear up to and including $4 \mathrm{mg}$ glycerol $/ 100 \mathrm{ml}$. Any serum with a glycerol concentration higher than this should be appropriately diluted with isotonic saline and reestimated.

FREE GLYCEROL

In preliminary experiments, by omitting the saponification procedure, the free glycerol in the serum before saponification was also estimated. As this was always less than $1 \mathrm{mg} / 100 \mathrm{ml}$, even in very lipaemic sera, a parallel free glycerol estimation was omitted as a routine procedure.

\section{BLANK ESTIMATIONS}

It is necessary to carry out a blank determination on every test. Omission of the blank results in a $10-30 \%$ overestimation of the serum triglyceride level.

\section{REPRODUCIBILITY}

The within-batch reproducibility of the method was checked by assaying a pooled serum 20 times. The mean value was $34.2 \mathrm{mg} / 100 \mathrm{ml}$ with a SD of 0.737 and a coefficient of variation of $2 \cdot 2 \%$. It was not possible to do a between-batch reproducibility because of the instability of serum glyceride glycerol which necessitated samples being analysed within $24 \mathrm{hr}$ of collection.

RECOVERY

Recovery experiments were carried out using tributyrin, triolein, and tripalmitin. The tributyrin $\frac{\rho}{\overline{5}}$ was dissolved in ethanolic $\mathrm{KOH}(0.5 \mathrm{~N})$, and the 0 triolein and tripalmitin in chloroform, before $\frac{\mathcal{O}}{\vec{\sigma}}$ addition to the serum and saponification. The average recovery of tributyrin was $97.8 \%$ with $\mathrm{a} \underset{\overrightarrow{\vec{F}}}{\mathrm{~g}}$ range of 93.3 to $104.4 \%$, of triolein $97 \%$ with a range of 90.5 to $104.5 \%$, and of tripalmitin? $94.2 \%$ with a range of 90.3 to $97.2 \%$.

\section{CARRY-OVER}

The carry-over from one specimen to the next» was checked by running $4 \mathrm{mg} / 100 \mathrm{ml}$ standards followed by water and then by $1 \mathrm{mg} / 100 \mathrm{ml} \stackrel{\circ}{\circ}$ standards as in the procedure described. The $\vec{\omega}$ carry-over was found to be nil.

NORMAL RANGE

The normal range (95\% limits) for glyceride $\%$ glycerol in serum was established by estimating 0 the fasting (morning) levels and the postprandial $\odot$ levels (one to two hours after lunch) in 24 male응 and female members of the hospital staff whoseages ranged between 22 and 62 years. The normal $\mathbb{D}$ fasting range was 2.5 to $15.5 \mathrm{mg} / 100 \mathrm{ml}$ and the normal range postprandially was 2.5 to $18 \mathrm{mg} / \frac{\mathbb{\Phi}}{3}$ $100 \mathrm{ml}$. The fasting values showed no significant ${ }_{\Phi}$ difference either between males and females $(t=1 \cdot 54, P>0 \cdot 1)$ or between under and over $\vec{\theta}$ 30 years age groups $(t=0.93, P>0.2)$. When $O$ the postprandial values were divided into two groups, under 30 years and over 30 years of age, the values in the younger group were found to be significantly lower than those in the older age group $(t=3.34, P<0.005)$. When the post- $\mathbb{Q}$ prandial values were divided according to sex $\stackrel{2}{\vec{F}}$ the males were found to have significantly higher $\frac{0}{3}$ triglyceride levels than the females $\left(t=2 \cdot 84, \frac{3}{5}\right.$ $\mathbf{P}<0.01$; Fig. 3). Eighteen samples were tested both fasting and postprandially and 12 of these showed a rise in glyceride glycerol in the postprandial state. These results are shown $\frac{0}{3}$ graphically in Figure 4. It is interesting to note that the range of normal fasting values is 0 apparently the same whatever the age and sex

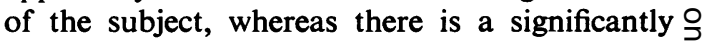
higher postprandial value in older subjects and $\rightarrow$ in males. This finding is to be investigated on a larger series, and if confirmed, may be important in relation to the problems of serum lipids and disease.

\section{SAPONIFICATION}

In preliminary experiments saponification of the triglycerides was carried out with alcoholic potassium hydroxide and the $p \mathrm{H}$ value adjusted 7 with perchloric acid before analysis to be within the range 6 to 8 . This method was time consum- $\stackrel{\square}{\stackrel{D}{\square}}$ ing, and trouble was encountered due to precipi- $\stackrel{\mathbb{D}}{\unrhd}$ tation of fatty acids during analysis causing turbidities. For this reason the saponification method of Schmidt and Dahl (1968), where the fatty acids are precipitated by magnesium before 
maLe and fEMALE VALUES ( FASTING)

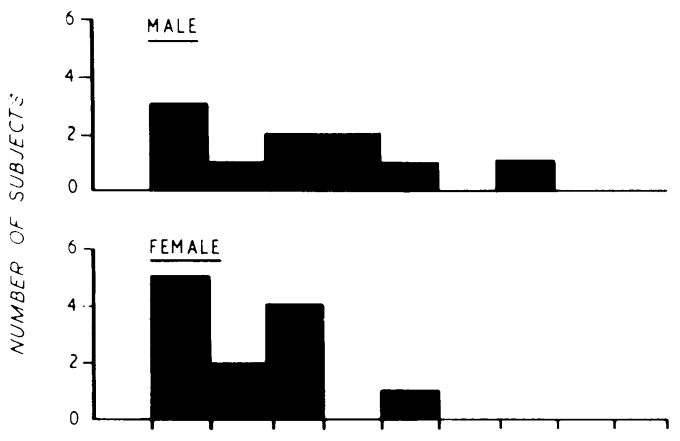

male and female Values post prandial
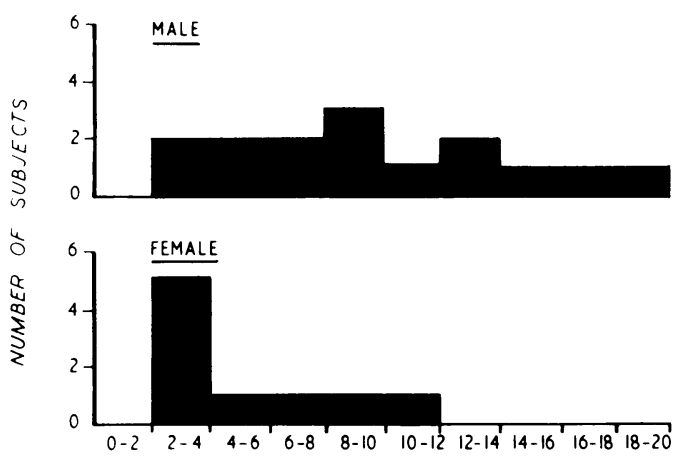

GLYCERIDE GLYCEROL $\mathrm{mg} / 100 \mathrm{ml}$

Fig. 3 Histograms of normal glyceride glycerol values according to age, sex, and absorptive state.

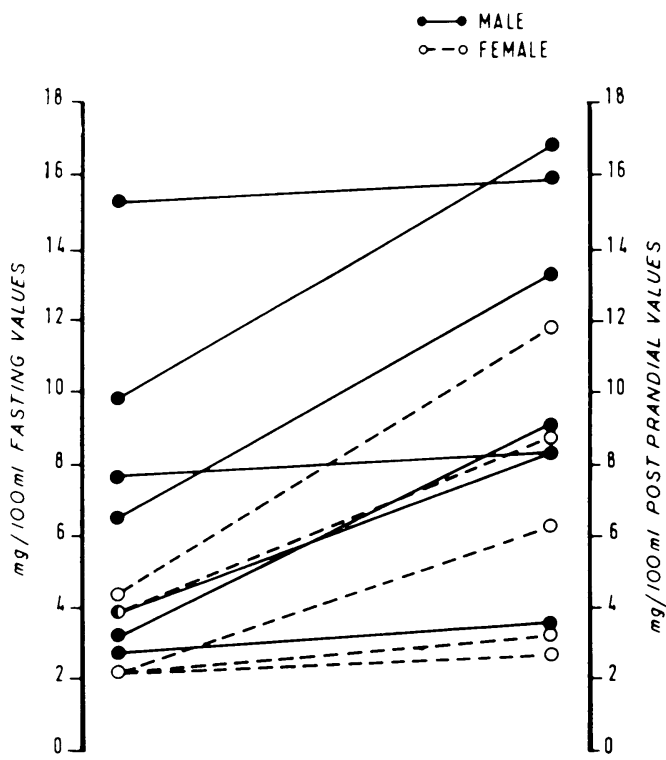

Fig. 4 Comparison of fasting and postprandial glyceride glycerol levels.
UNDER 30 AND OVER 30 AGEGROUPS (FASTING)
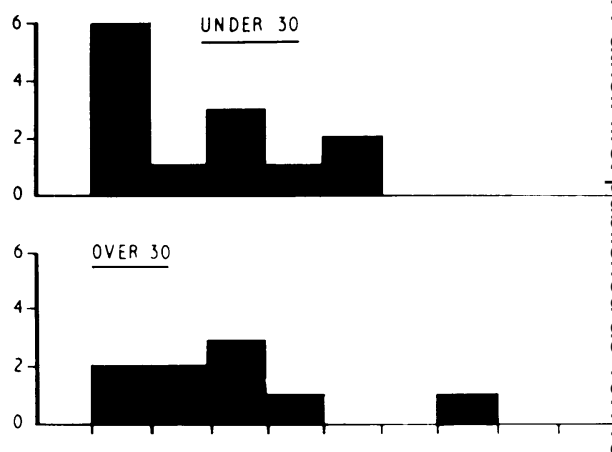

UNDER 30 AND OVER 30 AGEGROUPS POST PRANDIAL
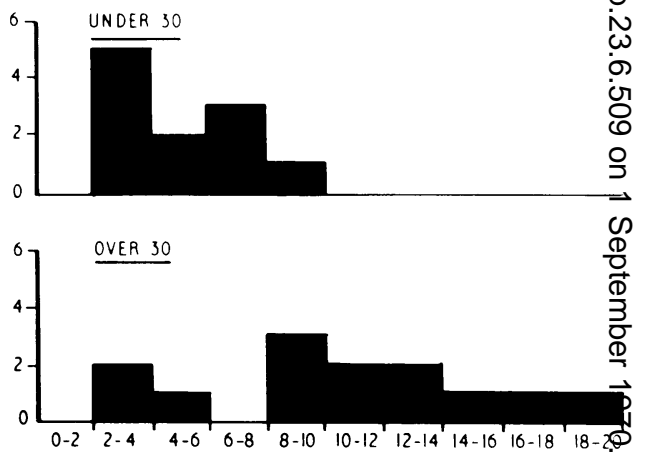

GLYCERIDE GLYCEROL $\mathrm{mg} / 100 \mathrm{ml}$

analysis of glycerol, was adopted and found to $\bar{\Phi}$ e satisfactory for analysis of serum. The methords of Sperry (1955) and Folch, Lees, and Staney (1957) were also tried but although these we also satisfactory for saponification the direct method described was preferred because of greater simplicity.

\section{KEEPING PROPERTIES OF GLYCERIDE}

GLYCEROL

The keeping properties of glyceride glycerol we investigated both in the serum and in ge saponified extract. The specimens were kept isi series of covered tubes at $-20 \mathrm{C}, 4 \mathrm{C}$, and 25 . The value found for glyceride glycerol in the serwan and for the glycerol in the saponified extrais was stable for $24 \mathrm{hr}$, then increased on keeping $\mathrm{f}_{\mathrm{t}}$ all temperatures, reaching a plateau at abedt three days: it is therefore necessary to use fresh serum for this analysis. This phenomenon requibes further study. COMPARISON BETWEEN AUTOMATIC AND $\frac{0}{\mathbb{0}}$
MANUAL PROCEDURES

The Table shows a comparison between the p $\frac{\text { Pe}-}{}$ sent automatic procedure and the manual entymatic method of Eggstein and Kreutz (1966). The free glycerol concentration was consistently hig@er with the manual method than with the automaked 


\begin{tabular}{|c|c|c|c|c|}
\hline \multirow[t]{2}{*}{ Sample } & \multicolumn{2}{|c|}{ Free Glycerol $(\mathrm{mg} / 100 \mathrm{ml})$} & \multicolumn{2}{|c|}{$\begin{array}{l}\text { Glyceride Glycerol (free glycerol not } \\
\text { subtracted })(\mathrm{mg} / 100 \mathrm{ml})\end{array}$} \\
\hline & AutoAnalyzer & Manual & AutoAnalyzer & Manual \\
\hline 1 & 0.8 & 1.4 & $23 \cdot 3$ & $24 \cdot 0$ \\
\hline 2 & 0.8 & 1.6 & $25 \cdot 3$ & $24 \cdot 0$ \\
\hline 3 & 0.6 & $1 \cdot 1$ & $20 \cdot 4$ & $19 \cdot 8$ \\
\hline 4 & 0.9 & 1.5 & $19 \cdot 5$ & $19 \cdot 8$ \\
\hline 5 & 0.6 & 1.6 & $13 \cdot 2$ & $14 \cdot 0$ \\
\hline 6 & 0.5 & $1 \cdot 3$ & $15 \cdot 4$ & $13 \cdot 0$ \\
\hline 7 & $0 \cdot 6$ & $2 \cdot 2$ & $13 \cdot 2$ & $13 \cdot 0$ \\
\hline 8 & 0.9 & $1 \cdot 1$ & $14 \cdot 3$ & $14 \cdot 0$ \\
\hline
\end{tabular}

Table Present method and the manual enzymatic method compared

method. The values for total glyceride glycerol showed good agreement.

\section{EFFECT OF GLUCOSE}

Solutions of glucose $(50 \mathrm{mg} / 100 \mathrm{ml}$ and $100 \mathrm{mg} /$ $100 \mathrm{ml}$ in water) were run through the standard procedure in the same way as the glycerol solutions. The peaks obtained were read as 'glyceride-glycerol'. At both concentrations values equivalent to about $0.8 \mathrm{mg}$ glyceride glycerol/ $100 \mathrm{ml}$ were obtained.

\section{EFFECT OF PHOSPHOLIPIDS}

Concentrations of $\alpha$-lecithin between 50 and $250 \mathrm{mg} / 100 \mathrm{ml}$ (6 to $30 \mathrm{mg}$ lecithin glycerol) were added to a serum containing $10 \mathrm{mg}$ glyceride glycerol/100 $\mathrm{ml}$ and the samples run through the procedure. Lecithin is not measured by this procedure, shown by zero recovery of the added lecithin glycerol.

\section{Discussion}

The normal range found by this method is similar to that of the standard colorimetric procedure of Carlson and Wadström (1959), who found a normal range of 3.8 to $14 \mathrm{mg} / 100 \mathrm{ml}$ in the postabsorptive state in young men. Using this enzymatic procedure, Eggstein and Kreutz (1966) found a significantly wider range of 2 to $22 \mathrm{mg} / 100 \mathrm{ml}$ (mean $\pm 2 \mathrm{SD}$ ). The reason for this discrepancy is not clear.

The value for free serum glycerol was consistently lower by the AutoAnalyzer method than by the manual method. This may be due to the fact that in the AutoAnalyzer procedure a continuous running blank is used and subtracted from the test result, whereas in the manual procedure all the reagents except the glycero- kinase are mixed and the optical density is allowed $\frac{\varrho}{5}$ to reach a stable level before the addition of 0 glycerokinase and analysis of glycerol. It was practically always impossible to stabilize the optical density before the addition of glycero- $\overrightarrow{\vec{F}}$ kinase in the manual method even with a 'blank' period of one hour or more. The free glycerol in serum estimated by the present procedure was between 0.5 and $1.0 \mathrm{mg} / 100 \mathrm{ml}$ in the normal group tested: and similar results have been $\propto$ reported by Laurell and Tibbling (1966). It would appear that a considerable part, if not all, of the measured glycerol may be an artefact due to traces of hexokinase in the glycerokinase used. This hexokinase will convert any glucose present to glucose-6-phosphate with the production of ADP from the ATP present and this ADP will is continue through the enzymatic reactions used of for estimating glycerol. This does not occur in in total glyceride glycerol estimations as any glucose 6 present is destroyed by the saponification pro- 을 cedure. Solutions of glucose $(50 \mathrm{mg} / 100 \mathrm{ml}$ and $100 \mathrm{mg} / 100 \mathrm{ml}$ ), when run by the standard $\mathscr{D}$ glyceride glycerol procedure, both gave peaks equivalent to about $0.8 \mathrm{mg}$ glyceride glycerol/ $100 \mathrm{ml}$ which is approximately equal to the level of free glycerol estimated by this method in serum. A concentration of glucose of $50 \mathrm{mg} / 100 \mathrm{ml}$ thus appears to be sufficient to saturate the interfering enzymes.

This automated procedure for serum glyceride glycerol estimation has now been in use in this laboratory for six months and has proved to be simple to use and reproducible. The cost of reagents for these estimations is approximately 4 shillings $(£ 0.2)$ for each serum analysed.

\section{References}

Carlson, L. A., and Wadström, L. B. (1959). Determination of glycerides in blood serum. Clin. chim. Acta, 4, 197-205.

Eggstein, M. (1966). Eine neue Bestimmung der Neutralfette im Blutserum und Gewebe. Klin. Wschr., 44, 267-273.

Eggstein, M., and Kreutz, F. H. (1966). Eine neue Bestimmung der Neutralfette im Blutserum und Gewebe. Klin. Wschr., 44, 262-267.

Folch, J., Lees, M., and Stanley, G. H. S. (1957). A simple method for the isolation and purification of total lipids from animal tissues. J. biol. Chem., 226, 497-509.

Kessler, G., and Lederer, H. (1965). Fluorometric measurement of triglycerides. In Automation in Analytical Chemistry, O Technicon Symposium, pp. 341-344.

Laurell, S., and Tibbling, G. (1966). An enzymatic fluorometric micromethod for the determination of glycerol. Clin. chim. Acta., 13, 317-322.

Lofland, H. B., Jr. (1964). A semiautomated procedure for the determination of triglycerides in serum. Analyt. Biochem., 9, 393-400.

Schmidt, F. H., and Dahl, K. von (1968). Zur Methode der enzymatischen Neutralfett-Bestimmung in biologischem Material. Z. klin. Chem. 3, 156-159.

Sperry, W. M. (1955). Lipid analysis. Meth. Biochem. Anal., 2, 83-111.

Wieland, O. (1957). Eine enzymatische Methode zur Bestimmung von Glycerin. Biochem. Z., 329, 313-319. 